\title{
ENGLISH AND EMPLOYABILITY IN INDIA IN THE GLOBALIZATION ERA
}

\author{
B.Lakshmaiah \\ Teaching Associate \\ Department of English \\ Andhra University Campus \\ Vizianagaram \\ Email: lakshmanenglish@gmail.com
}

\begin{abstract}
This paper is intended to expose the problem of unemployment in India, and how English language has become a means of globalization. English language has occupied a predominant place in the third world countries. It also deals with how lack of skills in English communication is causing unemployment growth in India. This paper also shows the relationship between English communication skills and economic development of a country. It also studies how digital illiteracy has become a stumbling block for employability.
\end{abstract}

Key Words: Globalization, Unemployment, Employability Digital Illiteracy.

\section{English and globalization}

English language has made globalization possible. Without English we cannot imagine the world how it would have been. The world has become a village. People can go to any country to do jobs. People feel at home even in foreign countries only because of English language. English has made communication possible among of the people of different countries. Today's world considers English as a global language because there has never been a language so widely spread or spoken by so many people as English. It has a special role to play in the countries where it has been accepted as at the official language and is used as a medium of communication. English now holds a dominant position in every sphere of human activity. It is a very significant input in all the developments in the world. It has reached the present status primarily because of two main factors- the expansion of British Empire in the nineteenth century and the emergence of the United States as the leading economic power of the twentieth century.

English is used by enormous speech community, probably of six hundred million people, of whom about three hundred million are speakers of English as their mother tongue, while a further three hundred million have learned it in addition to their mother tongue.

It is most surprising that English has become the top language. It has emerged as an important component in industries and in all the spheres of a society's life- the press, advertising, broadcasting, motion pictures transport and communication. It has also become a leading language of political, 
ELK

Asia Pacific Journals

academic and community meetings. As the development of computers has been entirely an American phenomenon, the first computer operating systems used English vocabulary and syntax for instructions. Even the recent operating systems continue in English. Thus, growing a glowing influence of English can be anticipated as the sophistication increase in science and society. And definitely English will hold its predominant position in all human activities.

English has become a very important vehicle for education and employment in the third world countries particularly. Referring to third world countries such as Indian subcontinent, the west indies or Africa, Kachru says : "In these countries the English language is not taught as a vehicle to introduce British or American culture. In these countries, English is a link in culturally and linguistically pluralistic societies, and to maintain a continuity and uniformity in educational administrative and legal systems."

For the development of individuals and countries English is playing a crucial role. British Council believes that " English is critical for countries' successful participation in the global economy, that it provides individuals with access to crucial knowledge, skills and employment opportunities and enables organizations to create and sustain international links." English plays a role in national economic development whereas community languages are more likely to play a role in human needs development. An educated workforce
ELK Asia Pacific Journals - Special Issue

ISBN: 978-81-930411-1-6

is necessary though not sufficient for rapid economic development. In other words, a work force possessing English language skills is attractive feature for multinationals seeking new manufacturing locations. Thus English is not only providing facilities to individuals but also to the countries to develop and to withstand the competition of the other countries. Nowadays without English any country in the world will become isolated.

\section{English and Employability in India}

Unemployment has become a worldwide burning problem in the twenty first century. In India it one of the biggest problems as the educated youth more in number compared to other countries. But Dr. APJ kalam, the former president of India, said "India does not have the problem of unemployment but unemployability. India is the only country that consists of the highest percentage of youth population in the world. Five million graduates are produced annually in India. Only half of them are employable in any sector. The key factors that are holding back the students from employability are inadequacy in English skills and computer skills.

\section{English and International student mobility}

The movement of students from their mother country to other foreign universities is also a well recognized phenomena. The importance of English in international student mobility has been well recognized for many years, as manifested in the 
international English language competency tests- IELTS and TOEFL- which most receiving institutions and visa issuing authorities require to pass. Approximately $45 \%$ of the world total of international students are studying just in four countries: USA, UK, Australia and Canada. And 27\% of the student are studying in France, Germany, China and Japan. But only who studied in English medium schools and those who are financially sound are going abroad to study. But the students who are studying in vernacular schools are not able to compete with English medium students in English qualifying tests. So special care must be taken by the governments to develop rural area students.

\section{Digital Illiteracy}

English has become the language of internet. It has become a source accessing information. And it is a means of international communication between researchers and scholars. Today, throughout the world, if we want to have any information from internet it is available only in English. So many students are not able to avail of facility that internet is providing. Today many courses are being offered through online. But if the students want to take any course online again English is mandatory. English is also the language of library. All the books are available in English. Since they lack the communication skills in English it becomes very difficult for them to make use of that material. The National Employability Report by Aspiring Minds, an employability solutions company tested communication skills in English, computer knowledge, analytical and cognitive skills and basic accounting knowledge of sixty thousands Indian graduates. The report reveals that women show similar or higher employability compared to men. About sixteen percent of the graduates were employable in sales and fourteen percent customer service where communication skills and personality skills like friendliness and negotiation skills are much required. Over one third of the graduates $(36 \%)$ were suitable for employment in clerical/ secretarial jobs. When it comes to IT services IT operations , only $13 \%$ and $16 \%$ are employable respectively.

\section{Difference of Employability between urban and rural students}

Any job requires competence and cognitive skills along with English. But because of the differences in study atmosphere and facilities, there is a huge gap between education in urban and rural areas. It was found that the higher the skill requirement for a job, the greater the gap between employability in urban and rural students. In rural areas students don't have facilities of computer education at least to do certificate courses in computer education. They have to come to towns and cities. And it involves financial matters. Some of them cannot afford the money.so there are many differences in the ways of education, facilities and cultures .There is a difference in employability chances between urban and rural students. Students from cities are 
ELK

Asia Pacific Journals

getting jobs compared to rural background students. People coming from villages are found poor at English language skills even at post-graduation level. `Aspiring Minds survey reveals, thorough the test it conducted on topics like grammar and communication other quantitative skills to 32,000 MBA graduates form 220 business schools across India, that only $10 \%$ of those tested had skills required for recruiters. And $70 \%$ of engineering graduates are unemployed I India. The students coming from villages are not able to get jobs in consulting, banking, marketing and sales. Having all other skills without English communication skills is mere waste. Acquiring real competence in English is a privilege. As Coleman said English has become a passport to development, and it must be strictly available to all who desire it ,otherwise it becomes a means of barring to the less privileged.

Thus English definitely individuals' employability, enables international collaboration and cooperation, provides research information, and facilitates the international mobility of students. The
ELK Asia Pacific Journals - Special Issue

ISBN: 978-81-930411-1-6

Indian Government is spending crores of rupees on education. They are even planning to give wi-fi connections to the villages. The state governments are planning to establish special skill development universities. . But for whom? But how many people will get jobs is a question. So, English undoubtedly plays a major role in various aspects of development. Nevertheless, it is important that we should not exaggerate the importance of English nor we should undervalue the importance of other languages. We must our enthusiasm for English with a sense of responsibility towards those who do not have easy access to it.

Reference:

[1] The Hindu, Nov.12, 2011.

[2] The Hindu, Jun.26, 2013.

[3] The Times of India,Jun.23,2013.

[4] Peter Stevens, English as an International Language, the British Council, ELT Documents , London, 1978.

[5] Hywel Coleman, The English Language in Development, The British Council, London, 2010 